\title{
Preferensi Serangga Herbivora Henosepilachna sp (Coleoptera: Coccinellidae) terhadap Beberapa Jenis Tanaman Budidaya
}

\author{
Preference of Henosepilachna sparsa (Coleoptera: Coccinellidae) Herbivore Insect on Several \\ Types of Cultivated Plants
}

\section{Rein Estefanus Senewe}

Balai Pengkajian Teknologi Pertanian (BPTP) Maluku, Jln. Chr. Soplanit Rumah Tiga Ambon, 97234

E-mail Penulis Korespondensi: reinsenewe@gmail.com

\begin{abstract}
Herbivorous insects and plants have a very complex interaction relationship, where plants play an important role in shaping the behavior and development of herbivorous insects. Nutrients contained in plants in the form of secondary compounds also determine whether or not plants were selected by insects. The objective of the research was to study the preferences of Henosepilachna sparsa herbivorous insects on several cultivated plants. The study was conducted in October 2013 at the Toxicology Laboratory, Department of Plant Protection, Faculty of Agriculture, Bogor Agricultural University. The steps of the experiments were: a) Extracting plant materials such as takokak, eggplant, tomatoes, and broccoli using hexane and methanol solvents; and b) imago H. sparsa preference of plant was takokak plant extract with methanol solvent, takokak plant material with Hexane solvent, tomato plant with Methanol solvent, tomato plant material with Hexane solvent, eggplant plant material with Methanol solvent, eggplant material with Hexane solvent, broccoli with Methanol solvent), broccoli plant material with Hexane solvent was carried out using a three-branched olfactometer (Y form). Imago H. sparsa of plant extract was taken from around the taro plant in Bogor. The results of the study show that the imago H. sparsa insect preference test for extraction of test plants using hexane solvents was better than methanol solvents. Extraction of eggplant plants with hexane solvents has the highest retention value (Rf) of $0.751 \mathrm{~cm}$ with the assumption that the higher the Rf value, the more metabolites are detected.
\end{abstract}

Keywords: allelochemics, attractants, broccoli, eggplant, repellent, tomatoes, takokak

\begin{abstract}
ABSTRAK
Serangga herbivora dan tanaman memiliki hubungan interaksi yang sangat kompleks, dimana tanaman mempunyai peran yang penting dalam membentuk perilaku dan perkembangan serangga herbivora. Nutrisi yang dikandung tanaman berupa senyawa sekunder juga menentukan dipilih atau tidak dipilih suatu tanaman oleh serangga. Penelitian bertujuan untuk mempelajari preferensi serangga herbivora Henosepilachna sparsa pada beberapa tanaman budidaya. Penelitian dilaksanakan pada bulan Oktober 2013 di Laboratorium Toksikologi, Departemen Proteksi Tanaman Fakultas Pertanian, Institut Pertanian Bogor. Tahapan penelitian meliputi: a) Ekstraksi bahan-bahan tanaman seperti takokak, terung, tomat, dan brokoli dengan menggunakan pelarut heksana dan metanol; dan b) Preferensi imago H. Sparsa terhadap ekstrak bahan tanaman takokak dengan pelarut Metanol, bahan tanaman takokak dengan pelarut Heksana, bahan tanaman tomat dengan pelarut Metanol, bahan tanaman tomat dengan pelarut Heksana, bahan tanaman terung dengan pelarut Metanol, bahan tanaman terung dengan pelarut Heksana, bahan tanaman brokoli dengan pelarut Metanol, bahan tanaman brokoli dengan pelarut Heksana dilakukan menggunakan olfaktometer yang bercabang tiga (bentuk Y). Imago H. sparsa diambil dari sekitar pertanaman talas di Bogor. Hasil penelitian menunjukkan bahwa uji preferensi serangga imago H. sparsa terhadap ekstraks tanaman uji menggunakan pelarut heksana lebih baik dari pelarut metanol. Ekstraksi tanaman terung dengan pelarut heksana memiliki nilai retensi tertinggi (Rf) $0,751 \mathrm{~cm}$ dengan dugaan bahwa semakin tinggi nilai Rf maka semakin banyak senyawa metabolit yang terdeteksi.
\end{abstract}

Kata Kunci: allelokemik, atraktan, brokoli, repelen, takokak, terung, tomat 


\section{PENDAHULUAN}

Serangga herbivora dan tanaman memiliki hubungan interaksi yang sangat kompleks. Serangga sebagai organisme heterotrop, tidak bisa eksis tanpa adanya tanaman hijau yang berfungsi sebagai sumber utama senyawa kaya energi. Serangga harus memakan organisme lain untuk mendapatkan molekul-molekul kaya energi untuk tumbuh, berkembang dan bereproduksi (Schoonhoven et al., 2005). Sehingga tanaman mempunyai peran yang penting dalam membentuk perilaku dan perkembangan serangga herbivora (Ehrlich dan Raven, 1967). Whittaker dan Feeny (1971) menyatakan serangga dan tanaman dihubungkan oleh senyawa kimia yang disebut allelokemik yang merupakan faktor penentu dalam seleksi serangga terhadap tanaman. Senyawa-senyawa esensial (metabolit primer) pada tanaman merupakan faktor penentu dalam seleksi tanaman oleh serangga. Nutrisi atau zat hara yang dikandung tanaman (senyawa sekunder) juga menentukan dipilih atau tidak dipilih suatu tanaman oleh serangga (Kennedy, 1965).

Selain faktor fisik tumbuhan, faktor kimia (senyawa-senyawa kimia) memainkan peranan penting dalam seleksi inang (host selection) oleh serangga. Serangga dapat mengenali atau merasakan keberadaan senyawa kimia dalam jumlah/konsentrasi rendah di dalam makanannya. Senyawa-senyawa yang telah dikenal baik oleh serangga akan dijadikan tanda bahwa tanaman tersebut adalah inang mereka dan kebanyakan senyawa-senyawa yang telah dikenal dijadikan sebagai penarik (atraktan). Sebaliknya kehadiran senyawasenyawa yang belum dikenal (foreign compounds) dapat mengakibatkan penolakan pada serangga. Inilah yang mendasari mengapa serangga memilih inang tertentu dan tidak memilih inang yang lain. Penolakan serangga terhadap kehadiran senyawa-senyawa kimia tertentu dapat dimanfaatkan untuk dikaji lebih mendalam tentang aspek pengendalian serangga hama (Dadang dan Prijono, 2008).

Senyawa-senyawa yang terkandung di dalam tanaman, dapat menunjukkan berbagai macam aktivitas biologi pada serangga seperti penghambatan/penolakan makan, penolakan peneluran, penghambatan pertumbuhan dan perkembangan, kematian dan lain-lain (Dadang dan Prijono, 2008). Nonpreference merupakan sifat tanaman yang menyebabkan suatu serangga menjauhi atau tidak menyenangi suatu tanaman baik sebagai pakan atau sebagai tempat peletakan telur. Menurut Kogan (1982) istilah yang lebih tepat digunakan untuk sifat ini adalah antixenosis yang berarti menolak tamu. Antixenosis dapat dikelompokkan menjadi penolakan kimiawi atau antixenosis kimiawi dan penolakan morfologi atau antixenosis morfologi. Antixenosis kimiawi terjadi karena tanaman mengandung allelokimia yang menolak kehadiran serangga pada tanaman. Antixenosis morfologi, ketahanan tanaman disini terbawa oleh adanya sifat-sifat struktural atau morfologi tanaman yang dapat menghalangi terjadinya proses makan dan peletakan telur yang normal. Informasi tentang berbagai spesies tumbuhan yang memiliki bioaktivasi terhadap berbagai jenis serangga banyak dilaporkan. Saat ini lebih dari 1500 spesies tumbuhan dari berbagai famili telah dilaporkan dapat berpengaruh buruk terhadap serangga (Grainge dan Ahmed, 1988).

Proses pemilihan inang oleh serangga dilakukan dengan beberapa cara seperti melalui penglihatan (visual), penciuman (olfaktori), pencicipan (gustatori) dan perabaan (taktil). Metcalf dan Luckmann (1975) mengemukakan bahwa proses pemilihan inang oleh serangga melalui beberapa tahap, yaitu: 1) pencarian habitat inang (host habitat finding); mencari habitat inang dengan mempergunakan mekanisme yang melibatkan fototaksis, geotaksis, preferensi tempat dan kelembaban; 2) pencarian inang (host finding); pada umumnya mempergunakan mekanisme yang melibatkan tanggap olfaktori dan penglihatan; 3) pengenalan inang (host recognition); adanya rangsangan olfaktori, rasa dan raba akan membantu serangga mengenal inang; 4) penerimaan inang (host acceptance) ; adanya senyawasenyawa kimia khas yang dikandung inang akan membuat serangga dapat menerima inang tersebut; dan 5) kesesuaian inang (host suitability) ; tanaman yang tidak mengandung racun tetapi mengandung zat makanan yang sesuai akan menunjang proses perkembangbiakan serangga.

Sebagai langkah awal dalam rangkaian kegiatan pengujian aktivitas biologi tumbuh-tumbuhan yang dianggap atau diduga mempunyai pengaruh biologi pada suatu organisme adalah melalui ekstraksi atau suatu metode yang digunakan untuk mengambil produk dari bahan alami seperti dari jaringan tumbuhan. Untuk menarik komponen non polar dari suatu jaringan tumbuh-tumbuhan tertentu dibutuhkan pelarut non polar seperti petroleum eter atau heksana, sedangkan pelarut polar seperti etanol atau metanol untuk menarik komponen yang lebih polar. Metode ekstraksi yang tepat tergantung pada tekstur dan kandungan air bahan-bahan yang akan diekstrak serta tipe senyawa yang akan diisolasi. Proses ekstraksi yang dilakukan diantaranya dengan metode perendaman, maserasi, perkolasi dan soksletasia (Dadang dan Prijono, 2008).

Tanaman takokak (Solanun torvum Swartz), terung (Solanum melongea L), tomat (Lycopersicum esculentum Mill), dan brokoli (Brassica oleracea L) merupakan tanaman sayur-sayuran yang banyak dibudidayakan karena banyak dikonsumsi oleh masyarakat luas. Keempat jenis tanaman ini diteliti tentang aspek hubungan serangga dengan tanaman. Serangga Henosepilachna (= Epilachna) sparsa (Hrbst) (Coleoptera: Coccinellidae) banyak berasosiasi dan umumnya menimbulkan kerusakan pada tanamam kelompok Solanaceae. Di Indonesia, serangga ini dapat 
ditemukan sampai pada ketinggian 2000 mdpl atau dari dataran rendah sampai dengan dataran tinggi. Tanaman takokak ( $S$. torvum) merupakan inang utama dari serangga ini, tetapi imago serangga ini dapat ditemukan juga pada tanaman kentang dan kecubung (Pseudodatura suaveolens) tetapi tampaknya kurang selektif dibandingkan dengan larva. Siklus hidup serangga dapat mencapai tiga bulan pada suhu yang dingin, dan betina dapat meletakkan telur mencapai 800 buitr setiap 30 hari (Kalshoven, 1981). Bentuk tubuhnya oval, berwarna merah atau cokelat kekuning-kuningan, panjang antara 6-7 mm. Betina bertelur pada permukaan daun bagian bawah sebanyak 20-50 butir. Telur berwarna kuning, bentuknya oval, dan panjang $0,5 \mathrm{~mm}$. Setelah 4 atau 5 hari larvanya akan keluar dan dapat memakan daun-daun buncis. Pupa berbentuk segi empat dan bergerombol pada daun, tangkai, atau batang. Setelah stadia larva adalah stadia dewasa (kumbang) yang sangat rakus memakan daun-daunan, dan hidupnya dapat mencapai lebih dari 3 bulan. Tanaman inangnya bukan hanya jenis kacang-kacangan saja, tetapi juga mentimun, padi, jagung, kubis, dan tanaman lain dari family Solanaceae. Berdasarkan hal ini, penelitian bertujuan untuk mempelajari preferensi serangga herbivora Henosepilachna sparsa pada beberapa tanaman budidaya.

\section{METODE PENELITIAN}

Penelitian dilaksanakan di Laboratorium Toksikologi, Departemen Proteksi Tanaman Fakultas Pertanian, Institut Pertanian Bogor, Oktober 2013. Penelitian dilakukan dalam dua tahapan, yaitu (a) Ekstraksi bahan-bahan tanaman yaitu takokak (Solanun torvum Swartz), terung (Solanum melongea L), tomat (Lycopersicum esculentum Mill), dan brokoli (Brassica oleracea L) dengan menggunakan pelarut heksana dan metanol, dan (b) Preferensi imago H. Sparsa terhadap ekstrak TAM (bahan tanaman takokak dengan pelarut Metanol), TAH (bahan tanaman takokak dengan pelarut Heksana), TOM (bahan tanaman tomat dengan pelarut Metanol), TOH (bahan tanaman tomat dengan pelarut Heksana), TEM (bahan tanaman terung dengan pelarut Metanol), TEH (bahan tanaman terung dengan pelarut Heksana), BOM (bahan tanaman brokoli dengan pelarut Metanol), BOH (bahan tanaman brokoli dengan pelarut Heksana) dilakukan menggunakan olfaktometer yang bercabang tiga (bentuk Y). Imago H. sparsa diambil dari sekitar pertanaman talas di Bogor. Ekstrak TAH, TOH, TEH, BOH, TAM, TOM, TEM, dan BOM masingmasing ekstrak diambil diletakkan pada wadah kertas saring $(1 \mathrm{~cm} \times 1 \mathrm{~cm})$ (satu tetes per wadah). Kedua ujung olfaktometer, masing-masing diletakkan ekstrak (secara bergantian mis: TAH vs TOH, TAH vs TEH, TAH vs $\mathrm{BOH}, \ldots$, TAH vs BOM) dan di ujung yang satu dimasukkan $H$. sparsa (Gambar 1). Pemeriksaan kuantitatif dari masing-masing ekstrak dilakukan dengan
Kromatografi Lapis Tipis (KLT) ketebalan (0,1 mm dan $1 \mathrm{~mm})$.

Proses ekstraksi meliputi : Bahan segar daun tanaman tomat, takokak, terung, dan brokoli masingmasing di potong-potong dengan berat masing-masing bahan tanaman $30 \mathrm{gr}$ dan dimasukkan ke dalam tabung eleymeyer yang sudah berisi $200 \mathrm{ml}$ pelarut. Ekstrak diberi label TAM (bahan tanaman takokak dengan pelarut Metanol), TAH (bahan tanaman takokak dengan pelarut Heksana), TOM (bahan tanaman tomat dengan pelarut Metanol), TOH (bahan tanaman tomat dengan pelarut Heksana), TEM (bahan tanaman terung dengan pelarut Metanol), TEH (bahan tanaman terung dengan pelarut Heksana), BOM (bahan tanaman brokoli dengan pelarut Metanol), dan $\mathrm{BOH}$ (bahan tanaman brokoli dengan pelarut Heksana), dan direndam selama 24 jam. Selanjutnya masing-masing diambil cairan ekstraknya di centrifus dengan rotary evaporator pada suhu sekitar 40$50^{\circ} \mathrm{C}$.

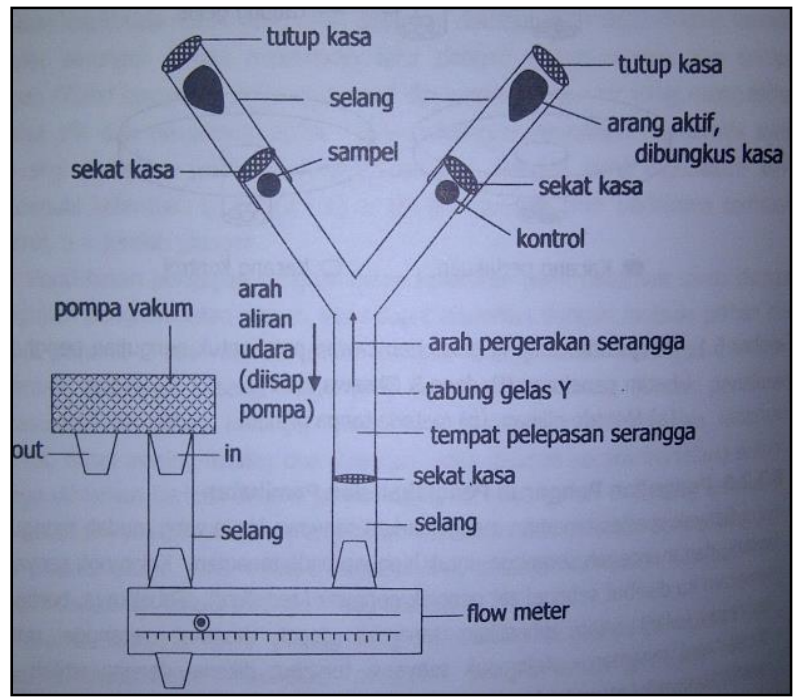

Gambar 1. Pemasangan olfaktometer untuk menguji repelen dan atraktan (Sumber: Dadang dan Prijono 2008)

Pengujian awal respon serangga terhadap (repelen dan atraktan) dilakukan dengan menggunakan olfaktometer berbentuk huruf Y yang terbuat dari kaca (Gambar 1) (Dadang dan Prijono 2008). Bahan uji diletakkan pada wadah kertas saring $(1 \mathrm{~cm} \times 1 \mathrm{~cm})$ dengan konsentrasi tertentu (satu tetes per wadah) dalam bagian ujung salah satu lengan olfaktometer, sedangkan di bagian ujung lengan lainnya diletakkan bahan uji yang lain sebagai pembanding. Serangga uji diletakkan satu per satu secara bergantian di dekat ujung tangkai olfaktometer. Setelah semua bagian olfaktometer dipasang, pompa pengisap dijalankan dengan laju aliran udara diatur sesuai yang diinginkan. Hasil ini akan terlihat setiap preferensi serangga ke bagian lengan tertentu yang terdapat tetesan ekstrak (Gambar 2). 

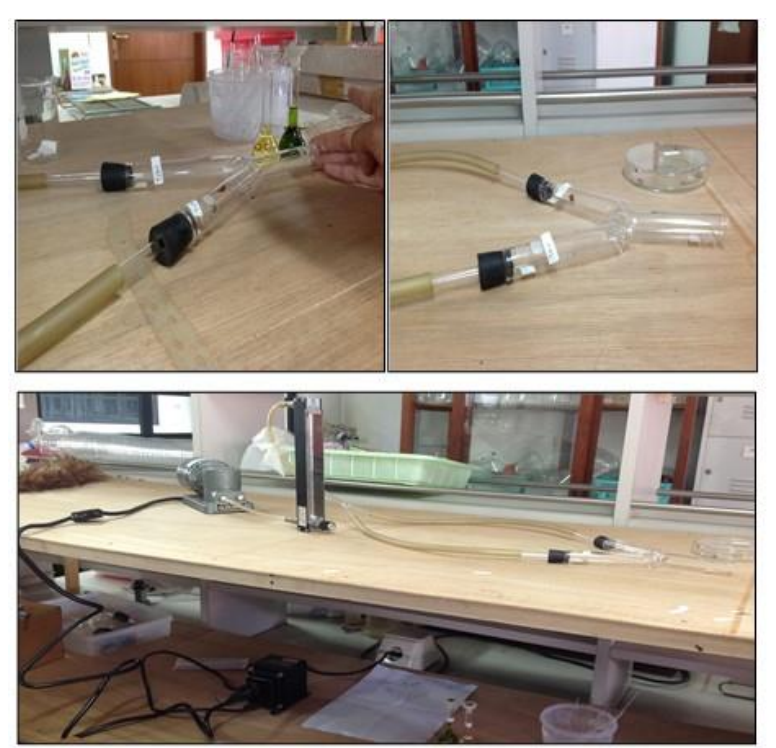

Gambar 2.Komponen uji preferensi serangga dengan pemasangan olfaktometer, serangga uji, dan bahan ekstrak tanaman

\section{HASIL DAN PEMBAHASAN}

Sebagaimana pada serangga fitofagus terutama Henosepilachna sparsa, terdapat hubungan antara tanaman dengan serangga. Hubungan tersebut dapat terjadi secara fisik maupun secara kimiawi terutama dengan adanya senyawa yang mudah menguap dan mampu menolak (repelen) maupun menarik (atraktan) kehadiran serangga ke tanaman inang. Rangsangan yang bisa menarik serangga secara umum berupa rangsangan bau yang dikeluarkan oleh tanaman inang dan tergolong senyawa kimia hasil metabolisme sekunder (Miller dan
Miller, 1986). Berbagai cara pengujian ketertarikan serangga fitofagus terhadap tanaman inang dapat dilakukan baik secara alami maupun buatan. Secara alami ketertarikan dapat dilakukan dengan cara pemaparan bahan tanaman (daun, batang, atau buah) di lapangan dan secara buatan dengan pemberian ekstrak bahan tanaman pada suatu tempat.

Tabel 1. Preferensi imago serangga $H$. sparsa pada jenis ekstrak dengan pelarutnya

\begin{tabular}{ccc}
\hline \multirow{2}{*}{ Tanaman } & \multicolumn{2}{c}{$\begin{array}{c}\text { Preferensi imago terhadap } \\
\text { ekstrak dengan pelarut ... }(\%)\end{array}$} \\
\cline { 2 - 3 } & Metanol & Heksana \\
\hline Takokak & 20 & 80 \\
Terong & 40 & 60 \\
Tomat & 20 & 80 \\
Brokoli & 20 & 80 \\
\hline
\end{tabular}

Hasil penelitian menunjukkan bahwa ekstraksi tanaman takokak, terong, tomat dan brokoli menggunakan pelarut heksana menunjukkan presentase rata-rata preferensi imago lebih baik daripada pelarut metanol (Tabel 1). Faktor ini karena pelarut heksana memiliki sifat non-polar sehingga komponen senyawa kimia yang terkandung dalam jaringan daun tanaman dapat terdeteksi lebih baik dibandingkan dengan pelarut polar metanol. Ekstraksi merupakan proses penarikan komponen zat aktif suatu bahan dengan menggunakan pelarut tertentu. Tujuan dari proses ini adalah untuk mendapatkan bagian-bagian tertentu dari bahan yang mengandung komponen-komponen aktif (Harborne 1984).

Tabel 2. Preferensi imago serangga $H$. sparsa terhadap ekstrak tanaman dengan pelarut heksana

\begin{tabular}{|c|c|c|c|}
\hline & Perlakuan & \multicolumn{2}{|c|}{ Preferensi serangga } \\
\hline \multirow{3}{*}{$\begin{array}{l}\text { Takokak dengan } \\
\text { pelarut heksana }\end{array}$} & Tomat dengan pelarut heksana & $\begin{array}{l}100 \% \text { ke tomat dengan pelarut } \\
\text { heksana }\end{array}$ & \\
\hline & Terung dengan pelarut heksana & $\begin{array}{l}100 \% \text { ke terung dengan pelarut } \\
\text { heksana }\end{array}$ & \\
\hline & Brokoli dengan pelarut heksana & $\begin{array}{l}100 \% \text { ke brokoli dengan pelarut } \\
\text { heksana }\end{array}$ & \\
\hline \multirow{2}{*}{$\begin{array}{l}\text { Tomat dengan } \\
\text { pelarut heksana }\end{array}$} & Terung dengan pelarut heksana & $\begin{array}{l}60 \% \text { ke tomat dengan pelarut } \\
\text { heksana }\end{array}$ & $\begin{array}{l}40 \% \text { ke terung dengan } \\
\text { pelarut heksana }\end{array}$ \\
\hline & Brokoli dengan pelarut heksana & $\begin{array}{c}60 \% \text { ke tomat dengan pelarut } \\
\text { heksana }\end{array}$ & $\begin{array}{l}40 \% \text { ke brokoli dengan } \\
\text { pelarut heksana }\end{array}$ \\
\hline $\begin{array}{l}\text { Terung dengan } \\
\text { pelarut heksana }\end{array}$ & Brokoli dengan pelarut heksana & $\begin{array}{l}60 \% \text { ke terung dengan pelarut } \\
\text { heksana }\end{array}$ & $\begin{array}{l}40 \% \text { ke brokoli dengan } \\
\text { pelarut heksana }\end{array}$ \\
\hline \multirow{3}{*}{ Aseton } & Tomat dengan pelarut heksana & $\begin{array}{l}80 \% \text { ke tomat dengan pelarut } \\
\text { heksana }\end{array}$ & $20 \%$ ke Aseton \\
\hline & Terung dengan pelarut heksana & $\begin{array}{c}100 \% \text { ke terung dengan pelarut } \\
\text { heksana }\end{array}$ & \\
\hline & Brokoli dengan pelarut heksana & $\begin{array}{c}80 \% \text { ke brokoli dengan pelarut } \\
\text { heksana }\end{array}$ & $20 \%$ ke Aseton \\
\hline
\end{tabular}


Penggunaan pelarut heksana pada tanaman takokak, tomat, terung dan brokoli umumnya menunjukkan tingkat preferensi tinggi atau persentase ketertarikan serangga. Tanaman takokak merupakan salah satu inang dari serangga $H$. sparsa, sehingga menjadi pembanding atau indikator terhadap tanaman terung, tomat dan brokoli. Hasil ini menunjukkan bahwa masing-masing ekstrak tanaman terung, tomat, dan brokoli dengan menggunakan pelarut heksana, rata-rata $100 \%$ tingkat preferensi serangga. Sedangkan senyawa aseton juga menunjukkan preferensi serangga hanya $20 \%$, tetapi tanaman terung dengan pelarut heksana jika dibandingkan dengan senyawa aseton (tanpa ekstrak tanaman), $100 \%$ preferensi serangga lebih memilih tanaman terung dengan pelarut heksana (Tabel 2). Preferensi imago serangga $H$. sparsa terhadap ekstrak tanaman dengan pelarut heksana yang masing-masing dibandingkan dengan senyawa aseton, menunjukkan bahwa $100 \%$ serangga lebih memilih tanaman terung, $80 \%$ serangga memilih tanaman tomat dan $80 \%$ ke tanaman brokoli. Faktor ini menunjukkan bahwa pelarut heksana berkolerasi positif dengan ekstrak tanaman, sehingga dapat diduga bahwa serangga $H$. sparsa memiliki inang yang luas atau berasosiasi dengan beberapa jenis tanaman. Faktor preferensi atau ketertarikan serangga terhadap berbagai jenis tanaman, antara lain berhubungan erat dengan senyawa kimia yang terkandung pada berbagai jenis tanaman seperti kelompok terpenoid, alkohol dan fenol yang telah diisolasi serta diteliti peranannya dalam mempengaruhi aktivitas serangga (Dadang dan Ohsawa, 2000). Golongan terpenoid terdiri atas isoprena, monoterpenoid, seskuiterpenoid, diterpenoid, triterpenoid dan poliisoprena. Golongan senyawa nitrogen hasil metabolit sekunder yang paling banyak terdapat dalam tumbuhan ialah alkaloid. Alkaloid merupakan golongan terbesar dari senyawa hasil metabolit sekunder pada tumbuhan, serta merupakan jenis racun yang paling sering ditemukan dalam tanaman yang dilaporkan berperan sebagai penolak atau pemikat serangga. Struktur kimianya beragam, tetapi umumnya berupa senyawa basa yang mengandung satu atau lebih atom nitrogen yang merupakan bagian dari sistem siklik. Racun yang dihasilkan biasanya berpengaruh terhadap sistem saraf (Dadang dan Prijono, 2008).

Hasil pengamatan menunjukkan bahwa ekstrak tanaman terung dengan pelarut heksana memiliki nilai retensi (Rf) $0,751 \mathrm{~cm}$ (Tabel 3) dengan dugaan bahwa semakin tinggi nilai Rf maka semakin banyak senyawa metabolit yang terdeteksi. Senyawa yang lebih polar akan "menempel" ke silika gel polar dan perjalanan jarak pendek pada pelat, sedangkan zat non-polar akan berdifusi ke dalam pelarut dan perjalanan jarak besar di piring. Ukuran jarak perpindahan senyawa disebut Rf, berkisar antara nol dan satu, ditentukan dengan mengukur jarak perpindahan senyawa dari baseline (titik awal) dibagi dengan jarak perpindahan pelarut dari baseline. Dalam suatu ekstrak tumbuhan, selain beberapa senyawa aktif utama biasanya juga terdapat banyak senyawa lain yang kurang aktif, namun keberadaannya dapat meningkatkan aktivitas ekstrak secara keseluruhan (sinergi). Menurut Ansel (1989), ekstraksi dapat dilakukan dengan dua cara yaitu fase cair dan fase organik. Cara fase cair dilakukan dengan menggunakan air, sedangkan cara fase organik dilakukan dengan menggunakan pelarut organik.

Pelarut heksana memberikan preferensi imago tertinggi pada ekstrak tanaman terung, diikuti oleh ekstrak tanaman tomat dan ektrak tanaman brokoli. Berdasarkan prinsipnya, proses ekstraksi dapat berlangsung bila terdapat kesamaan dalam sifat kepolaran antara senyawa yang diekstrak dengan senyawa pelarut. Suatu zat memiliki kemampuan terlarut yang berbeda dalam pelarut yang berbeda. Hal ini menunjukkan adanya interaksi antara zat telarut dengan pelarut. Senyawa polar akan larut pada pelarut polar (Metanol) juga, begitu juga sebaliknya dengan pelarut non polar (Heksana).

Tabel 3. Perbandingan rata-rata nilai retensi ekstrak tanaman

\begin{tabular}{|c|c|c|c|c|}
\hline Ekstrak & $\begin{array}{c}\text { Nilai retensi } \\
\text { (Rf) } \\
\text { Heksana } \\
\text { (cm) }\end{array}$ & $\begin{array}{c}\text { Nilai retensi } \\
\text { (Rf) } \\
\text { Heksana } \\
\text { diklorometane } \\
(\mathrm{cm}) \\
\end{array}$ & $\begin{array}{l}\text { Nilai Retensi } \\
\text { (Rf) Metanol } \\
(\mathrm{cm})\end{array}$ & $\begin{array}{c}\text { Nilai retensi } \\
\text { (Rf) } \\
\text { Metanol } \\
\text { diklorometane } \\
(\mathrm{cm}) \\
\end{array}$ \\
\hline Tomat dengan pelarut metanol & 0,042 & 0,255 & 0,553 & 0,600 \\
\hline Tomat dengan pelarut heksana & 0,032 & 0,439 & 0,537 & 0,689 \\
\hline Terung dengan pelarut metanol & 0,063 & 0,263 & 0,637 & 0,576 \\
\hline Terung dengan pelarut heksana & 0,021 & 0,053 & 0,621 & $\mathbf{0 , 7 5 1}$ \\
\hline Takokak dengan pelarut metanol & - & 0,247 & 0,595 & 0,512 \\
\hline Takokak dengan pelarut heksana & 0,100 & 0,218 & 0,547 & 0,726 \\
\hline Brokoli dengan pelarut metanol & - & - & 0,600 & 0,458 \\
\hline Brokoli dengan pelarut heksana & - & 0,400 & 0,632 & 0,274 \\
\hline
\end{tabular}


Sifat penting yang harus diperhatikan dalam pemilihan pelarut adalah kepolaran senyawa yang dilihat dari gugus polarnya (seperti gugus $\mathrm{OH}, \mathrm{COOH}$, lain sebagainya). Hal ini yang perlu diperhatikan dalam pemilihan pelarut adalah selektivitas, kemampuan untuk mengekstrak, toksisitas, kemudahan untuk diuapkan, dan harga (Harborne, 1984). Metode ekstraksi yang tepat amat tergantung pada tekstur dan kandungan air bahanbahan yang akan diekstrak juga tipe-tipe senyawa yang akan diisolasi. Untuk ekstraksi umumnya bahan tanaman dalam keadaan kering angin telah dipotong-potong kecil atau bahkan telah dijadikan bentuk tepung melalui penggilingan dengan menggunakan penggiling/blender. Ekstraksi bisa dilakukan dengan beberapa cara, diantaranya dengan metode perendaman, metode maserasi, metode perkolasi, dan metode soksletasi (Dadang dan Prijono, 2008)

Preferensi/non preferensi atau disukai/tidak disukainya suatu tanaman oleh serangga sebagai tempat bertelur, berlindung, sebagai makanannya, atau perpaduan ketiganya, yang disebabkan oleh sifat fisik dan kimia yang ada pada tanaman. Rangsangan fisik tanaman berupa tebalnya kulit, panjang dan lebatnya bulu-bulu pada permukaan daun, besarnya stomata dan tebalnya lapisan kutikula, dimana berhubungan erat dengan preferensi serangga untuk mencicipi atau mengambil makan serta peletakan telur (oviposisi). Selain faktor fisik tumbuhan, faktor kimia (senyawasenyawa kimia) memainkan peranan penting dalam seleksi inang (host selection) oleh serangga. Serangga dapat mengenali atau merasakan keberadaan senyawa kimia dalam jumlah/konsentrasi rendah di dalam makanannya. Senyawa-senyawa yang telah dikenal baik oleh serangga akan dijadikan tanda bahwa tanaman tersebut adalah inang mereka dan kebanyakan senyawasenyawa yang telah dikenal dijadikan sebagai penarik (atraktan). Sebaliknya kehadiran senyawa-senyawa yang belum dikenal (foreign compounds) dapat mengakibatkan penolakan pada serangga. Inilah yang mendasari mengapa serangga memilih inang tertentu dan tidak memilih inang yang lain. Penolakan serangga terhadap kehadiran senyawa-senyawa kimia tertentu dapat dimanfaatkan untuk dikaji lebih mendalam tentang aspek pengendalian serangga hama (Dadang dan Prijono 2008).

Whittaker dan Feeny (1971) menyatakan serangga dan tanaman dihubungkan oleh senyawa kimia yang disebut allelokemik yang merupakan faktor penentu dalam seleksi serangga terhadap tanaman. Senyawasenyawa esensial (metabolit primer) pada tanaman merupakan faktor penentu dalam seleksi tanaman oleh serangga. Nutrisi atau zat hara yang dikandung tanaman (senyawa sekunder) juga menentukan dipilih atau tidak dipilih suatu tanaman oleh serangga. Schoonhoven et al. (2005) menyatakan juga bahwa sebagai organisme heterotrop, serangga tidak bisa eksis tanpa adanya tanaman hijau atau inang yang berfungsi sebagai sumber utama senyawa kaya energi. Serangga harus memakan organisme lain untuk mendapatkan molekul-molekul kaya energi untuk tumbuh, berkembang dan bereproduksi.

Tanaman juga berlakukan mekanisme ketahanan tanaman terhadap serangan hama pada tanaman, yaitu: antixenosis, antibiosis, dan toleran. Ketahanan melalui faktor fisik/morfologi tanaman merupakan bagian dari ketahanan antixenosis, artinya ketidakmampuan tanaman menjadi inang serangga hama karena adanya hambatan secara fisik atau morfologis dari tanaman. Ketahanan antibiosis lebih banyak dipengaruhi oleh senyawa metabolit sekunder yang dihasilkan oleh tanaman inang, yang menyebabkan kematian atau gangguan fisiologis pada serangga hama. Sedangkan toleran adalah ketahanan tanaman yang didasarkan pada kemampuan tanaman bertahan dari serangan hama atau pulih dari kerusakan (recovery) (Indrayani, 2008).

\section{KESIMPULAN}

1. Uji preferensi imago serangga Henosepilachna sparsa terhadap ekstrak tanaman takokak, terong, tomat dan brokoli menggunakan pelarut heksana lebih baik dari pelarut metanol.

2. Senyawa metabolit sekunder yang terdeteksi lebih tinggi terjadi pada ekstraksi tanaman terung dengan pelarut heksana.

\section{DAFTAR PUSTAKA}

Ansel. 1989. Pengantar Bentuk Sediaan Farmasi. Jakarta: UI Press.

Dadang, dan K. Ohsawa. 2000. Penghambat aktivitas makan larva Plutella xylostella (L). (Lepidoptera: Yponomeutidae) yang diperlakukan ekstrak biji Swietenia mahogany Jacq. (Meliaceae). Buletin Hama dan Penyakit 12: 27-32.

Dadang, dan D. Prijono. 2008. Insektisida Nabati: Prinsip, Pemanfaatan, dan Pengembangan. Penerbit: Departemen Proteksi Tanaman. Fakultas Pertanian, Institut Pertanian Bogor.

Ehrlich, P.R. and P.H. Raven. 1967. Butterflies and plants: A study in coevolution. Evolution 18: 586-608.

Grainge, M. and S. Ahmed. 1988. Handbook of Plants with Pest-Control Properties. New York : John Wiley \& Sons.

Harborne, J.B. 1984. Phytochemical Methods. Ed ke-2. New York: Chapman and Hall.

Indrayani, I.G.A.A. 2008. Peranan morfologi tanaman untuk mengendalikan pengisap daun, Amrasca biguttula (Ishida) pada tanaman kapas. Perspektif 7: 47-54. DOI: 10.21082/p.v7n1.2008.\%25p 
Kalshoven, L.G.E. 1981. Pest of crops in Indonesia. PT Ichtiar Baru-Van Hoeve, Jakarta.

Kennedy, J.S. 1965. Mechanism of host plant selection. Annals of Applied Biology 56: 317-322. DOI: 10.1111/j.1744-7348.1965.tb01242.x

Kogan, M. 1982. Plant Resistance In Pest Management. In; Metcalf, R.L., and W.H. Luckmann (Eds.). Introduction to Insect Pest Management. Second Edition. New York: John Wiley \& Sons. Pp 93-134.
Metcalf, R.L. and W. Luckmann. 1975. Introduction To Insect Pest Management. John Wiley and Sons, New York. 587 pp.

Schoonhoven, L.M., J.J.A. van Loon, and D. Marcel. 2005. Insect-Plant Biology. Second edition. Oxford University Press.

Whittaker, R.H. and P.P. Feeny. 1971. Allelochemics: Chemical interaction between species. Science 171: 757-770. 